\title{
PENGARUH PENAMBAHAN PGPR (Plant Growth Promoting Rhizobacteria) dan BUAH NANAS(Ananas comosus) TERHADAP SPESIFIKASI PUPUK ORGANIK CAIR RUMPUT LAUT Euchema cottonii
}

\author{
Effect of Adding PGPR (Plant Growth Promoting Rhizobacteria) and Pineapple (Ananas comosus) \\ for Specifications of Organic Liquid Fertilizer Euchema cottonii \\ Indriyanti, Eko Nurcahya Dewi dan Eko Susanto \\ Program Studi Teknologi Hasil Perikanan \\ Fakultas Perikanan dan Ilmu Kelautan, Universitas Diponegoro \\ Jl. Prof. Soedarto, SH, Tembalang, Semarang, Jawa Tengah - 50275, Telp/fax. +6224 747698 \\ Email: indriyanti156@gmail.com
}

Diserahkan tanggal 8 Desember 2016, Diterima tanggal 3 Januari 2017

\begin{abstract}
ABSTRAK
Euchema cottonii mengandung unsur mikro dan makro nutrien, serta zat pengatur tumbuh tanaman seperti auksin, giberelin, sitokinin, dan etilen sehingga sangat berpotensi sebagai pupuk organik penyubur tanaman. Penambahan buah nanas berfungsi sebagai sumber C, P, dan K pada ekstrak pupuk rumput laut cair. Penelitian ini bertujuan untuk mengetahui pengaruh penambahan bioaktivator PGPR (Plant Growth Promoting Rhizobacteria)dan buah nanas terhadap kandungan C-organik, nitrogen, fosfor, kalium, $\mathrm{pH}$, suhu, bakteri patogen, dan organoleptik warna. Material yang digunakan dalam penelitian ini adalah E. cottonii, PGPR, dan buah nanas.. Rancangan percobaan yang digunakan adalah Rancangan Acak Lengkap (RAL) dengan 4 perlakuan dan 3 ulangan yaitu perlakuan kontrol (A), penambahan PGPR dan buah nanas 40\% (B), penambahan PGPR dan buah nanas 50\% (C), dan penambahan PGPR dan buah nanas 60\% (C). Parameter yang diukur adalah C-organik, nitrogen, fosfor, kalium, $\mathrm{pH}$, suhu, bakteri pathogen, dan oraganoleptik warna. Data parametrik dianalisa dengan uji ANOVA. Hasil penelitian menunjukkan bahwa penambahan buah nanas yang berbeda memberikan pengaruh nyata terhadap kadar C-organik, fosfor, dan kalium $(\mathrm{p}<0,05)$, sedangkan nilai nitrogen tidak berbeda nyata. Perlakuan penambahan nanas 50\% akan meningkatkan kandungan nitrogen dua kali lebih besar dari pada kontrol. Perlakuan terbaik yaitu pada penambahan PGPR dan nanas $60 \%$ dengan kandungan $\mathrm{C}, \mathrm{P}, \mathrm{K}$ berturut-turut adalah 7,02\%, 3,44\%, dan $3,41 \%$.
\end{abstract}

Kata kunci: Euchema cottonii, Pupuk Oganik Cair, PGPR, Nanas

\begin{abstract}
Euchema cottoniicontains elements ofmicroandmacronutrients, andplantgrowth regulatorssuch asauxin, gibberellin, cytokinin, andethyleneso ithasgreat potentialas anorganicfertilizer forfertilisingcrops. Addition A. comosusserves asa source of C, P, and Kin theliquid organic fertilizer. This study aimedtodetermine the effect ofbio-activatorPGPRand $A$. comosus on the content ofC-organic, nitrogen, phosphorus, potassium, $\mathrm{pH}$, temperature, pathogens, and color. The materialusedin this studywereE.cottonii, PGPR, andA. comosus. This research wasexperimentallaboratoriesusing completely randomized designwith 4 differenttreatments and 3replications, namely control (A), addition ofPGPR and A. comosus 40\%(B), addition of PGPR and A. comosus $50 \%$ (C), and addition of PGPR and A. comosus $60 \%$ (D). Parametersmeasured wereC-organic, nitrogen, phosphorus, potassium, $\mathrm{pH}$, temperature, pathogens, and color organoleptic. Parametric datawere analyzed byANOVA. The results showedthat theaddition ofPGPRandA.comosussignificantly affect $(\mathrm{P}<0.05)$ to thelevels ofc-organic, phosphoruslevels, potassium levels, but not nitrogen levels. Addition of pineapple $50 \%$ will increase the nitrogen content twice higher than control. The best treatment is addition of PGPR and pineapple $60 \%$ with the content of C, P, K respectively $7.02 \%, 3.44 \%$ and $3.41 \%$.
\end{abstract}

Keywords: Euchema cottoni, Liquid Organic Fertilizer, PGPR, Ananas comosus

\section{PENDAHULUAN}

Indonesia merupakan salah satu produsen rumput laut yang terbesar di dunia, namun demikian, pemanfaatan rumput laut di dalam negeri hingga saat ini masih terbatas sebagai produk pangan, produk semi-jadi, serta beberapa produk kosmetik. Sedangkan penggunaan rumput laut yang tidak dapat digunakan sebagai bahan pangan dapat digunakan untuk bidang pertanian dan hortikultura masih belum banyak dilakukan (Sedayuet al.,2013). Salah satunya adalah Eucheuma cottonii,rumput laut ini banyak mengandung trace mineral $(\mathrm{Fe}$, $\mathrm{B}, \mathrm{Ca}, \mathrm{Cu}, \mathrm{Cl}, \mathrm{K}, \mathrm{Mg}$ dan $\mathrm{Mn}$ ) dan juga zat pengatur tumbuh (ZPT) seperti auksin, sitokonin, dan giberelin yang berguna untuk memacu pertumbuhan dan meningkatkan produksi 
tanaman dan berpotensi dapat dimanfaatkan sebagai pupuk alami (Basmal, 2010)

Saraswati dan Sumarno (2008) menyatakan bahwa pupuk organik cair selain memiliki banyak kelebihan juga memiliki kekurangan, yaitu salah satunya proses pembuatannya dengan metode fermentasi membutuhkan waktu yang lama hingga bermingu-minggu bahkan berbulan bulan, sehingga dibutuhkan katalisator untuk memprcepat proes fermentasi. Penambahan buah nanas pada pembuatan pupuk cair bertujuan untuk mempercepat proses fermentasi dan meningkatkan kandungan unsur hara dalam pupuk. Mikroorganisme membutuhkan karbon (C) sebagai sumber energi serta nitrogen (N) untuk mensintesis protein bagi pertumbuhan mikrooganisme itu sendiri yang selanjutnya dilepas kembali oleh salah satu komponen dalam organik cair. Menurut Setyawan (2010) dengan penambahan buah nanas dapat menghidrolisis ikatan peptida pada protein atau peptida menjadi molekul yang lebih kecil yaitu asam amino, sehingga dapat dimanfaatkan menjadi pupuk organik. Penggunaan enzim bromelin dapat mempercepat proses fermentasi pada pupuk cair rumput laut.

Pupuk organik cair dari rumput laut dapat diproduksi dengan teknologi fermentasi menggunakan bioaktivator yang bertujuan untuk mempercepat pembentukan pupuk cair. Bioaktivator yang biasa digunakan salah satunya adalah PGPR (Plant Growth Promoting Rhizobacteia). Beberapa bakteri dari kelompok PGPR adalah genus Rhizobium, Azotobacter, Azospirillum dan bakteri pelarut fosfat seperti genus Bacillus, Pseudomonas, Arthrobacter, Bacterium, dan Mycobacterium (Biswas et al., 2000). Bakteri Rhizobium, Azotobacter, Azospirillum dan bakteri pelarut fosfat mempunyai fungsi penting seperti dekomposisi bahan organik seperti protein, karbohidrat, jasad renik, mineralisasi senyawa organik, fiksasi hara, pelarut hara, nitrifikasi dan denitrifikasi.

Beberapa metode pembuatan pupuk cair rumput laut telah dilakukan sebelumnya, diantaranya adalah ekstraksi cairan rumput laut segar secara fisik, maupun ekstraksi dengan mengunakan alkali (Basmal, 2010). Pada metode tersebut, kandungan senyawa HPT dan unsur hara pupuk cair yang didapatkan masih belum optimal. Pada penelitian ini pembuatan pupuk cair rumput laut dari jenis rumput laut E.cottonii dilakukan dengan cara fermentasi untuk mendapatkan pupuk cair yang memiliki kandungan HPT yang tinggi, serta proses fermentasi yang lebih cepat yaitu 14 hari dari biasanya yang dilakukan 3 bulan.Penambahan buah nanas sebanyak 40\%, 50\%, dan 60\%, mengacu pada penelitian Hapsari dan Welasih (2010) bahwa diperoleh hasil terbaik terjadi pada kondisi : nutrien nitrogen pada konsentrasi enzim $40 \%$, nutrien fosfor dan kalium pada konsentrasi enzim $60 \%$.Tujuan penelitian ini adalah untuk melihat pengaruh penambahan PGPR dan buah nanas terhadap spesifikasi pupuk organik cair rumput laut $E$. cottonii yang berupa kandungan corganik, nitrogen, fosfor, dan kalium dan membandingkan dengan standarmenurut Peraturan Menteri Pertanian No. 28/Permentan/SR.130/5/2011tentang persyaratan teknis organik pada pupuk organik cair.

\section{METODE PENELITIAN}

\section{Materi}

Sampel digunakan dalam penelitian ini adalah rumput laut E. cottonii yang didapat dari perairan Yogyakarta. Bahan lain yang digunakan adalah buah nanas, PGPR, molase, dan aquadest.Alat yang digunakan yaitu yaitu waterbath, spektrofotometri, flamefotometri, sentrifuge, $\mathrm{pH}$ meter.

\section{Metode}

Rancangan percobaan yang digunakan dalam penelitian ini adalah Rancangan Acak Lengkap (RAL), dengan 4 perlakuan yaitu kontrol, PGPR dan nanas 40\%, PGPR dan nanas $50 \%$, dan PGPR dan nanas $60 \%$. Parameter yang diukur pada penelitian yaitu c-organik, nitrogen, fosfor, dan kalium, nilai $\mathrm{pH}$ dan suhuyang dalam pupuk organik cair setelah fermentasi selama 14 hari, bakteri patogen, dan organoleptik warna.

Data hasil penelitian dianalisa menggunakan program SPSS 16Analiys of varians (ANOVA). Apabila P menunjukkan perbedaan nyata pada taraf uji $95 \%$ maka dilanjutkan dengan uji Beda Nyata Jujur (BNJ) untuk mengetahui perbedaan antar perlakuan (Steel and Torrie, 1991).

\section{Persiapan sampel}

Rumput laut dicuci bersih,buah nanas dikupas untuk diambil daging buahnya yang masih segar dan dihancurkan dengan blender hingga halus. Larutan PGPR disiapkan dengan dosis $5 \mathrm{ml}$ PGPR dan $10 \mathrm{ml}$ molase pada 1 liter aquadest.

\section{Pengolahan pupuk organik cair (POC) rumput laut $E$. cottonii}

Rumput laut ditimbang 500 gram kemudian dimasukan kedalam stoples volume $250 \mathrm{ml}$ dan ditambahkan larutan PGPR dan buah nanas dengan konsentrasi 0\%, 40\%, 50\%, dan $60 \%$. Setelah itu ditutup rapat dan dilakukan fermentasi selama 14 hari dilakukan penyaringan menggunakan kertas saring sehingga mendapatkan filtrat.

\section{Uji C-organik Metode Walkley \& Black (Horwitz, 2000)}

Sampel pupuk cair organik dimasukkan ke dalam labu takar, ditambahkan $\mathrm{H}_{2} \mathrm{SO}_{4}$ pekat dan larutan $\mathrm{K}_{2} \mathrm{Cr}_{2} \mathrm{O}_{1} 1 \mathrm{~N}$, didiamkan 30 menit dan ditambahkan larutan $\mathrm{H}_{3} \mathrm{PO}_{4}$ pekat dan diencerkan dengan aquades hingga homogen, setelah itu diendapkan. Larutan disaring dan bagian yang bening diambil, kemudian dimasukkan ke dalam erlenmeyer dan ditambahkan aquades, dan 2 tetes indikator DPA. Campuran dititrasi dengan $\mathrm{F}_{\mathrm{e}} \mathrm{SO}_{4} \quad 0,5 \mathrm{~N}$ sampai terjadi perubahan warna menjadi kehijauan sampai biru, dengan blanko sebagai pembanding (a). Perhitungan C-organik adalah sebagai berikut:

$$
\begin{aligned}
& \text { C organik }(\%) \\
& =\frac{(b-a) \times N F e S O 4 \times 3 \times 10 \times \frac{100}{77} \times 100 \%}{\left(\frac{100}{100}+k a\right) \text { xsampel }(m a)}
\end{aligned}
$$

\section{Uji Nitrogen (Sudarmadji et al., 2007)}

Pupuk cair sebanyak $1 \mathrm{~g}$ dimasukkan ke dalam labu kemudian ditambah katalis $\mathrm{N}$ sebanyak $2 \mathrm{~g}$ dan $\mathrm{H}_{2} \mathrm{SO}_{4}$ pekat sebanyak $10 \mathrm{ml}$. Sampel ditambah $10 \mathrm{ml}$ aquadest dan $20 \mathrm{ml}$ larutan $\mathrm{NaOH}-\mathrm{Na}_{2} \mathrm{~S}_{2} \mathrm{O}_{3}$, kemudian batu didih dimasukkan ke dalam labu destilasi yang berisi sampel. Larutan $\mathrm{NaOH} 0,1 \mathrm{~N}$ sebanyak $50 \mathrm{ml}$ dimasukkan ke dalam gelas beker dan ditambah 3 tetes MR (Metil Red), sebagai penampungan. Sampel didestilasi hingga menghasilkan filtrat sebanyak $75 \mathrm{ml}$. Filtrat tersebut dititrasi $\mathrm{HCl} 0,02 \mathrm{~N}$ hingga berwarna kuning. Kadar Nitrogen dihitung dengan rumus:

(ㄷ) Copyright by Saintek Perikanan (Indonesian Journal of Fisheries Science and Technology), ISSN : 1858-4748 
Nitrogen $\%$

$=(\mathrm{A}-\mathrm{B}) \times \mathrm{N} \mathrm{HCl} \times 14.008 \mathrm{mg}$ sampel $\times 100 \%$ mg sampel

\section{Uji Fosfor (Horwitz, 2000)}

Pupuk cair sebanyak $5 \mathrm{~g}$ dimasukkan dalam labu digesti, kemudian ditambahkan $\mathrm{HNO}_{3} 5 \mathrm{ml}$ dan $\mathrm{HClO}_{4} 5 \mathrm{ml}$, dikocok-kocok dan dibiarkan semalam. Labu dipanaskan mulai dengan suhu $100^{\circ} \mathrm{C}$, setelah uap kuning habis suhu dinaikan hingga $200^{\circ} \mathrm{C}$. Destruksi diakhiri bila sudah keluar uap putih dan cairan dalam labu tersisa sekitar $5 \mathrm{ml}$. Larutan didinginkan dan diencerkan dengan aquadest dan volume ditepatkan menjadi $50 \mathrm{ml}$, dikocok hingga homogen, biarkan semalam didapat ekstrak jernih (ekstrak A).

Ekstrak A dipipet $1 \mathrm{ml}$ ke dalam tabung kimia volume $20 \mathrm{ml}$ ditambahkan $9 \mathrm{ml}$ aquades di homogenkan. Ekstrak ini adalah hasil pengenceran 10x (ekstrak B). Ekstrak B $1 \mathrm{ml}$ dimasukkan dalam tabung kimia volume $20 \mathrm{ml}$, begitupun masing-masing deret standar fosfor $(0 ; 1 ; 2 ; 4 ; 6 ; 8$; dan 10 ppm ). Sampel dibiarkan 15 - 25 menit, lalu diukur dengan spektrofotometer $693 \mathrm{NM}$ dan dicatat nilai absorbansinya. Kadar fosfor dihitung dengan rumus:

Kadar P (\%)

= ppm kurva x ml ekstrak 1.000 ml-1 x 100 mg contoh- 1 x fp x $31 / 95 \mathrm{x} \mathrm{fk}$

\section{Uji Kalium (BPT, 2005)}

Pupuk cair ditimbang $5 \mathrm{~g}$ dan dimasukkan dalam labu Kjeldahl. Kemudian $\mathrm{HNO}_{3}$ ditambahkan $5 \mathrm{ml}$ dan $\mathrm{HClO}_{4} 5 \mathrm{ml}$, dikocok-kocok dan dibiarkan semalam. Labu dipanaskan mulai dengan suhu $100^{\circ} \mathrm{C}$, setelah uap kuning habis suhu dinaikan hingga $200^{\circ} \mathrm{C}$. Destruksi diakhiri bila sudah keluar uap putih dan cairan dalam labu tersisa sekitar $5 \mathrm{ml}$. Larutan didinginkan dan diencerkan dengan aquadest dan volume ditepatkan menjadi $50 \mathrm{ml}$, dikocok hingga homogen, biarkan semalam atau disaring dengan kertas saring W-41 agar didapat ekstrak jernih (ekstrak A).

Ekstrak A dipipet $1 \mathrm{ml}$ ke dalam tabung kimia volume $20 \mathrm{ml}$, kemudian ditambahkan $9 \mathrm{ml}$ aquadest, dikocok dengan vortex mixer sampai homogen. Ekstrak ini adalah hasil pengenceran 10x (ekstrak B). K dalam ekstrak B diukur dengan flamefotometer atau SSA dengan deret standar sebagai pembanding $(0 ; 2 ; 4 ; 8 ; 12 ; 16$; dan 20 ppm K), dicatat emisi/absorbansi baik standar maupun contoh. Kadar K dihitung dengan rumus :

$\mathrm{K}(\%)$

$=$ ppm kurva $\times$ ml ekstrak $1.000 \mathrm{ml}-1 \times 100 \mathrm{mg}$ contoh- $1 \times \mathrm{fp}$ $\mathrm{x}$ fk

Pengukuran nilai pH (Balai Penelitian Tanah, 2005)

Setiap ekstrak dari setiap perlakuan diambil $10 \mathrm{ml}$ dimasukan kedalam beaker glass, selanjutnya diukur nilai $\mathrm{pH}$ dengan menggunakan alat $\mathrm{pH}$ meter.

\section{HASIL DAN PEMBAHASAN}

\section{Nilai C-organik}

Kandungan C-organik mengalami peningkatan pada setiap perlakuan (Gambar 1). Peningkatan C-organik disebabkan karena adanya penambahan nanas yang mengandung total karbon tinggi sekaligus penambahan bioaktivator sehingga mikroorganisme pada pupuk cair semakin banyak.

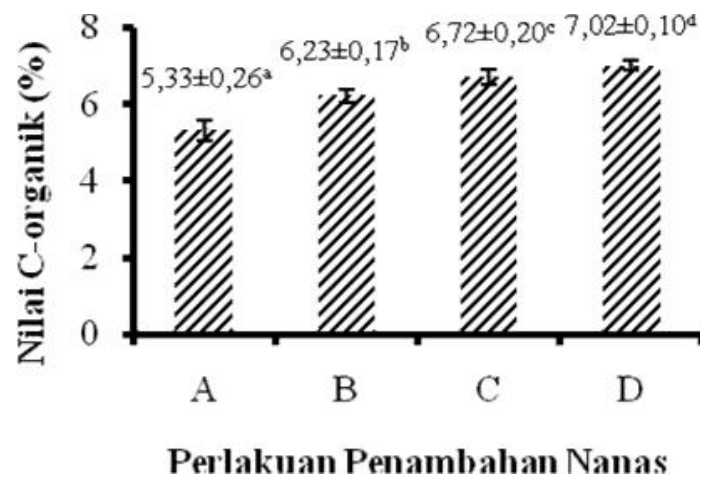

Gambar 1. Grafik Nilai C-organik Pupuk Cair Organik E.cottonii pada Fermentasi 14 Hari

Keterangan:

A = Rumput laut E.cottonii fermentasi kontrol

$\mathrm{B}=$ Rumput laut E.cottonii fermentasi dengan

PGPR dan buah nanas $40 \%$

$\mathrm{C}=$ Rumput laut E.cottonii fermentasi dengan

PGPR dan buah nanas $50 \%$

$\mathrm{D}=$ Rumput laut E.cottonii fermentasi dengan

PGPR dan buah nanas $60 \%$

Penambahan nanas dan PGPR ini mempengaruhi kandungan C-organik dikarenakan C-organik yang cukup tinggi yaitu mencapai $7,02 \%$ sehingga sampel yang ditambahkan buah nanas dan PGPR memiliki C-organik lebih tinggi dibandingkan kontrol. Menurut Illera-Vives et al. (2015) berbagai jenis unsur hara, terutama $\mathrm{N}$, disamping $\mathrm{P}, \mathrm{K}$ dan yang lain sebagai hasil penguraian, akan terikat dalam tubuh jasad renik.

Peraturan Menteri Pertanian No. 28/Permentan/SR.130/5/2011 tentang persyaratan teknis minimal kandungan $\mathrm{C}$-organik pada pupuk organik cair adalah min 6\%. Kandungan C-organik yang ada pada semua perlakuan pupuk organik telah memenuhi persyaratan teknis minimal dari Kementerian Pertanian. Apabila kandungan Corganik $<6 \%$ maka akan berdampak pada tanah yaitu masalah pencucian sekaligus kelambatan penyediaan hara pada tanah sehingga akan berakibat defisiensi unsur hara tanah.

\section{NilaiNitrogen}

Hasil penelitian menunjukkan bahwa kandungan nitrogen pada sampel A lebih rendah dibandingkan dengan sampel B, C, dan D. Kandungan nitrogen pada sampel B meningkat sebanyak $0,33 \%$ dari sampel $\mathrm{A}$, kemudian pada sampel C meningkat dua kali lipat yaitu sebanyak $0,67 \%$, akan tetapi kandungan nitrogen kembali menurun pada sampel $\mathrm{C}$ sebanyak $0,63 \%$ yaitu pada penambahan PGPR dan nanas 60\%. Menurut Hapsari dan Welasih (2010) hasil terbaik nutrien nitrogen yaitu pada konsentrasi enzim $40 \%$.

\footnotetext{
(ㄷ) Copyright by Saintek Perikanan (Indonesian Journal of Fisheries Science and Technology), ISSN : 1858-4748
} 


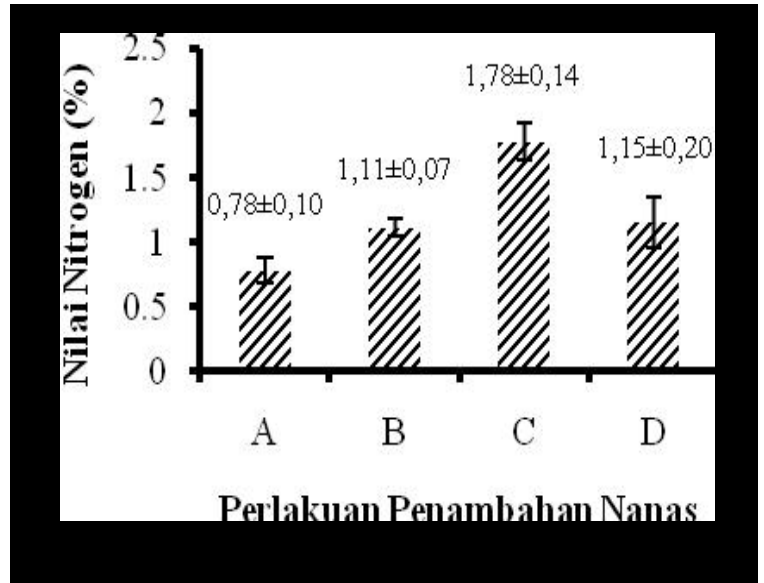

Gambar 2. Grafik Nilai Nitrogen Pupuk Cair Organik E.cottoniipadaFermentasi 14 Hari

Kenaikan kadar nitrogen pada sampel B dan C disebabkan aktivitas mikroorganisme yang terdapat dalam fermentasi pupuk cair rumput laut. Hal ini terjadi karena penambahan bioaktivator PGPR dan buah nanas sebanyak 40$50 \%$, maka mikroorganisme pada proses fermentasi menjadi semakin banyak. Hal ini sesuai dengan pendapat Citawaty (2011) bahwa kandungan amoniak yang ada di dalam fermentasi pupuk cair akan meningkat dan selanjutnya akan di ubah menjadi senyawa yang mudah di serap tanaman yaitu $\mathrm{NO}_{3}{ }^{-}$(nitrat) dan $\mathrm{NH}_{4}{ }^{+}$(amoniak).

Menurut Peraturan

Menteri PertanianNo.7/Permentan/SR.140/10/2011, persyaratteknis minimal kandungan $\mathrm{N}$ pada pupuk organik cair adalah 3-6 \%. Kandungan $\mathrm{N}$ yang ada pada perlakuan penambahan PGPR dan nanasbelum memenuhi persyaratan teknis minimal dari Kementerian Pertanian. Hal ini diduga karena pemberian pupuk cair rumput laut dekomposisinya berjalan lambat sehingga kandugan nitrogen setelah pemberian perlakuan tidak meningkat nyata sehingga belum dapat menaikkan kandungan nitrogen sampai batas minimal SNI yang ditetapkan.

\section{Nilai Fosfor}

Kandungan fosfor pada setiap perlakuan terus mengalami peningkatan karena adanya penambahan bioaktivator PGPR dan buah nanas (Gambar 3).Pemberian nanas pada konsentrasi $40 \%-50 \%$ mengandung sejumlah mikroorganisme yang menghasilkan enzim bromelin dan fosfatase yang cukup tinggi, sehingga proses asimilasi fosfor terjadi secara sempurna dan hasilnya meningkat.

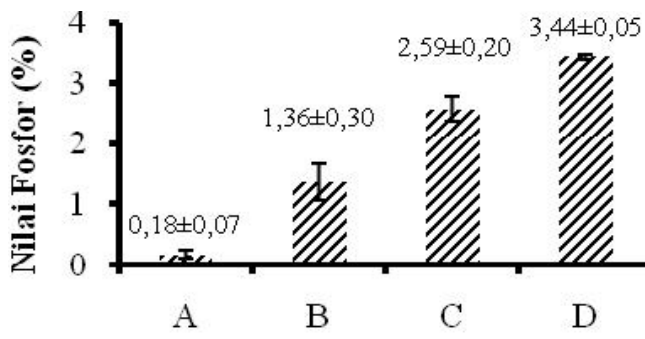

Perlakuan Penambahan Nanas

Gambar 3. Grafik NilaiFosfor Pupuk Cair Organik E.cottoniipada Fermentasi 14 hari
Peningkatan kandungan fosfor yang berbeda pada sampel D dengan konsentrasi 60\% dipengaruhi oleh kandungan nitrogen. Sampel D memiliki kandungan nitrogen yang lebih rendah. Stofella dan Kahn (2001) menyatakan bahwa kandungan $\mathrm{P}_{2} \mathrm{O}_{5}$ berkaitan dengan kandungan $\mathrm{N}$ dalam substrat, semakin besar nitrogen yang dikandung maka multiplikasi mikroorganisme yang merombak fosfor akan meningkat, sehingga kandungan fosfor dalam pupuk cair juga meningkat.

Kandungan fosfor pada suatu bahan seperti pupuk organik cair juga dipengaruhi oleh kandungan yang lainnya juga seperti kandungan nitrogen, berdasarkan penelitian dari Hidayati et al. (2011)yang menyatakan kandungan nitrogen kemungkinan berkaitan dengan jumlah mikroorganisme yang tumbuh. Semakin besar nitrogen yang dikandung maka multiplikasi mikroorganisme yang merombak fosfor akan meningkat, sehingga kadungan fosfor dalam pupuk akan meningkat.

Berdasarkan penelitian Irma dan Sari (2015) pada hasil analisis uji tanah dan pupuk, unsur $\mathrm{P}$ pada limbah cair nanas sebanyak $0,01 \mathrm{mg} / \mathrm{l}$ namun setelah diberikan ketanah, $\mathrm{P}$ tersedianya menjadi 35,38ppm pada tanah yang sudah terpapar satu kali. Hal ini dikarenakan pupuk limbah cair nanas membantu tanah mengikat $\mathrm{P}$ lebih banyak, sehingga tanaman mendapat unsur $\mathrm{P}$ bukan hanya dari limbah cair nanas saja namun dari tanah.

\section{Nilai Kalium}

Jumlah kalium dari keempat perlakuan menunjukkan hasil yang berbeda nyata. Kandungan kalium pada setiap perlakuan mengalami peningkatan. Peningkatan kandungan kalium didasarkan pada semakin banyaknya mikroorganisme yang terdapat pada pupuk cair akibat pemberian bioaktivator PGPR dan buah nanas. Hal ini terjadi karena semakin besar penambahan buah nanas maka kandungan K-total pada pupuk cair akan semakin besar pula.

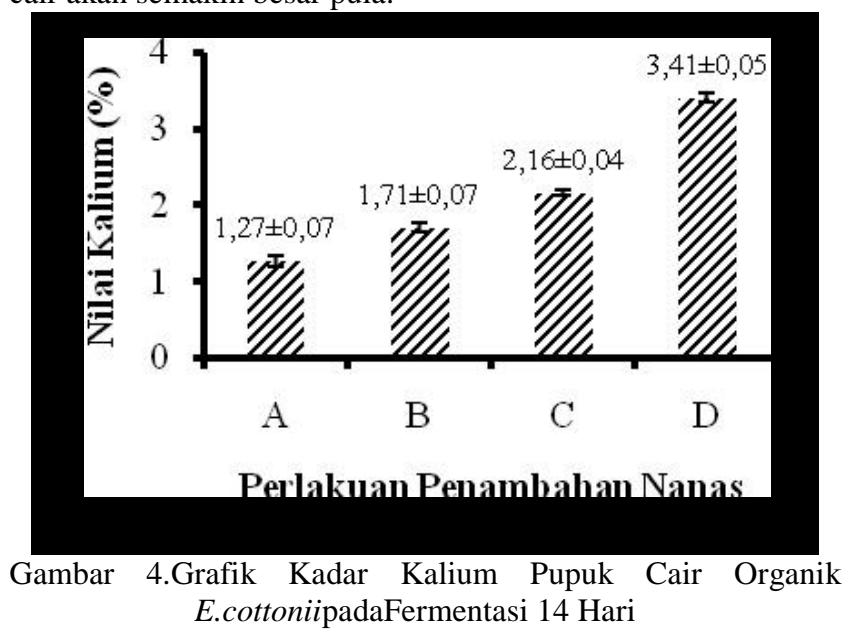

Hidayati et al. (2015) menyebutkan bahwa kalium digunakan oleh mikroorganisme dalam bahan substrat sebagai katalisator, dengan kehadiran bakteri dan segala aktifitasnya akan sangat berpengaruh terhadap peningkatan kandungan kalium. Kalium diikat dan disimpan dalam sel oleh bakteri dan jamur.

Menurut Peraturan Menteri Pertanian No.7/Permentan/SR.140/10/2011 persyaratan teknis minimal kandungan Kalium pada pupuk organik cair adalah 3-6\%. Kandungan kalium yang ada pada perlakuan penambahan

(C) Copyright by Saintek Perikanan (Indonesian Journal of Fisheries Science and Technology), ISSN : 1858-4748 
PGPR dan nanas $60 \%$ sudah memenuhi persyaratan teknis minimal dari Kementerian Pertanian. Menurut Kunstantini (2014) fungsi kalium pada tanaman yaitu dapat mempengaruhi kualitas rasa, warna, dan bobot pada buah dan bunga.

Kandungan kalium pada pupuk organik cair E.cottonii.pada perlakuan penambahan PGPR dengan penambahan buah nanaspada penelitian ini lebih tinggi dibandingkan dengan kandungan fosfor pada pupuk organik dari urin sapidengan penambahan limbah ikan dan buah nanas. Menurut Indriani (2013) nilai kandungan $\mathrm{K}_{2} \mathrm{O}$ pada pupuk cair urin sapi tanpa atau dengan penambahan limbah ikan dan buah nanas sebelum dan sesudah fermentasi meningkat yaitu dari $0,42 \%$ menjadi $1,37 \%$.

\section{Nilai pH}

Nilai pH pupuk rumput laut E.cottoniiyang difermentasi selama 14 hari dengan perlakuan yang berbeda tersaji pada Gambar5.

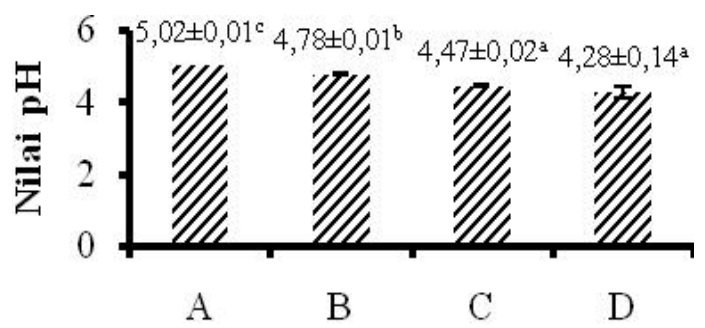

Perlakuan Penambahan Nanas

Gambar 5. Grafik Nilai pH Pupuk Cair Organik E.cottoniipada Fermentasi14 Hari

Data pada Gambar 8 menunjukkan bahwa terdapat perbedaan nilai $\mathrm{pH}$ pada kontrol dan pada perlakuan dengan penambahan buah nanas. Nilai $\mathrm{pH}$ pada setiap perlakuan mengalami penurunan. Nilai $\mathrm{pH}$ akan cenderung turun karena mikroorganisme yang dihasilkan dari penambahan PGPR dan buah nanas yang digunakan bersifat asam, dan cenderung berkembang cukup baik pada kondisi pH agak asam. Asamasam yang terbentuk seperti asam asetat, asam piruvat, dan asam laktat yang dapat menurunkan nilai $\mathrm{pH}$ lingkungan pertumbuhan mikroorganisme dan menimbulkan rasa asam.

Masuda et al. (2000) menyatakan bahwa pemberian bahan yang kaya akan karbohidrat fermentable dapat mempercepat penurunan $\mathrm{pH}$, karena karbohidrat fermentable merupakan energi bagi pertumbuhan bakteri pembentuk asam laktat dan asam laktat yang dihasilkan bereaksi dengan $\mathrm{NH}_{3}$.

Kandungan buah nanas yang bersifat asam mempengaruhi kandungan $\mathrm{pH}$ pada setiap sampel yang dilakukan. Menurut Ratnaningsih et al. (2009) pH yang terus menurun disebabkan proses metanogenesis tidak berjalan sempurna, bakteri penghasil asam tumbuh terlalu cepat sehingga asam yang dihasilkan akan lebih banyak dari jumlah yang dapat dikonsumsi oleh bakteri penghasil methan, akibatnya sistem akan terlalu asam.

$$
\text { Menurut Peraturan Menteri Pertanian }
$$

No.8/Permentan/SR.130/5/2011, persyaratan teknis minimal nilai $\mathrm{pH}$ pada pupuk organik cair adalah 4 - 8. Nilai $\mathrm{pH}$ yang ada pada semua perlakuan pupuk organik telah memenuhi persyaratan teknis minimal dari Kementerian Pertanian.Menurut Sutanto (2002) pada prinsipnya bahan organik dengan $\mathrm{pH}$ antara $3-11$ dapat difermentasikan, $\mathrm{pH}$ optimum berkisar antara $5,5-8$.

Suhu

Suhu pupuk cair pada setiap perlakuanmengalami kenaikan. Peningkatan suhu yang terjadi pada setiap perlakuan menandakan bahwa adanya aktivitas mikroorganisme yang terjadi pada proses fermentasi sehingga suhu meningkat(Gambar 6).

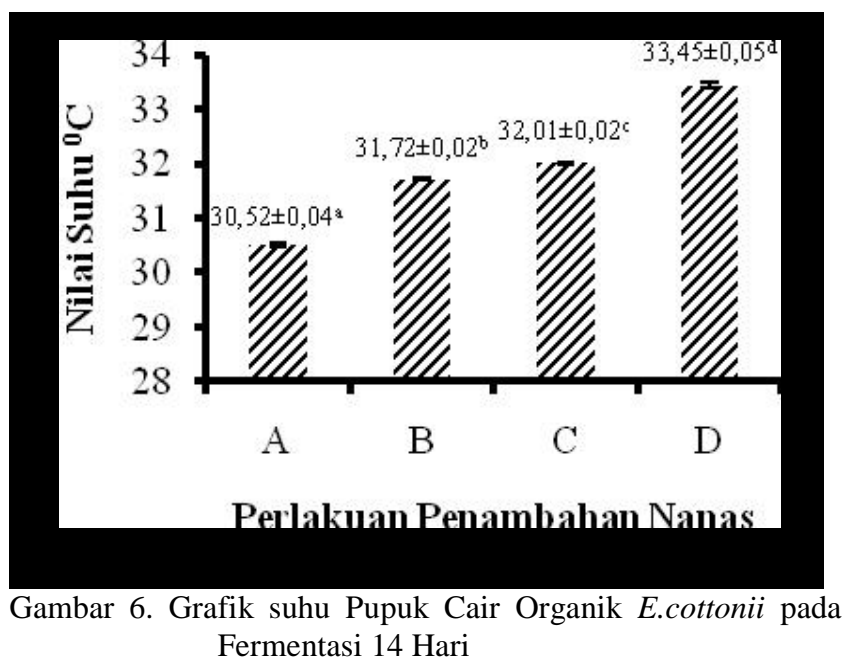

Pengukuran suhu pada pupuk cair organik dilakukan setelah fermentasi selama 14 hari. Data yang diperoleh yaitu suhu pada sampel perlakuan penambahan PGPR dan nanas mengalami kenaikan rata-rata sebanyak $10 \circ \mathrm{C}$ dari suhu kontrol, dimana suhu pada semua sampel berkisar antara 30,5 33,40 oC. Citawaty (2011) menyatakan bahwa suhu kurang dari $450 \circ \mathrm{C}$, proses fermentasi dibantu oleh mikroorganisme mesofilik yang berfungsi untuk memperkecil ukuran partikel bahan organik. Suhu fermentasi di atas 450C maka mikroorganisme yang berperan adalah mikroorganisme termofilik yang berfungsi untuk mengkonsumsi karbohidrat dan protein sehingga bahan fermentasi dapat terdegradasi dengan cepat. Aktivitas mikroorganisme termofilik akan berhenti ketika bahan makanan sudah habis hal ini ditandai dengan terjadinya penurunan suhu. Saat itu, mikroorganisme mesofilik akan memulai aktivitasnya kembali untuk merombak sisa proses sebelumnya menjadi gula yang sederhana.

Berdasarkan hasil pengukuran suhu pupuk cair setelah fermentasi selama 14 hari, suhu tertinggi terdapat pada perlakuan D yaitu $33,4^{0} \mathrm{C}$.

\section{Bakteri Patogen}

Semua POC negatif Salmonella $s p$ dan E. coli. Kandungan bakteri patogen pada pupuk rumput laut E.cottoniiyang difermentasi selama 14 hari tersaji pada Tabel 1. 
Pengaruh Penambahan Pgpr dan Buah Nanas terhadap Spesifikasi Pupuk Organik Cair Rumput Laut Euchema Cottonii

Tabel 1. Kandungan bakteri patogen pada pupuk organik cair E. cottonii secara kuantitatif

\begin{tabular}{llll}
\hline No & Bakteri & Perlakuan & $\begin{array}{l}\text { Hasil } \\
\text { Pemeriksaan }\end{array}$ \\
\hline 1 & $\begin{array}{l}\text { Escherichia } \\
\text { coli }\end{array}$ & A & Negatif \\
& & B & Negatif \\
& & C & Negatif \\
& & D & Negatif \\
2 & \multirow{2}{*}{ Salmonella sp } & A & Negatif \\
& & B & Negatif \\
& & C & Negatif \\
& & D & Negatif \\
\hline
\end{tabular}

Hal tersebut dapat disebabkan saat pembuatan POC dengan fermentasi dihasilkan panas yang menyebabkan kematian bakteri patogenik. Menurut Peraturan Menteri Pertanian No. 28/Permentan/SR.130/5/2009, persyaratan teknis minimal bakteri patogen E. coli dan Salmonella sp adalah Nol pada pengenceran 10-3 dengan metode MPN-Durham. Kandungan bakteri patogen yang ada pada semua perlakuan pupuk organik telah memenuhi persyaratan teknis minimal dari Kementerian Pertanian.

\section{Organoleptik Warna}

Menurut standar kualitas pupuk organik cair1 Permentan No. 70/Permentan/SR.140/10/2011 warna pupuk cair yang sudah matang adalah berwarna coklat kehitaman. Berdasarkan hasil pengamatan organoleptik warna yang terlihat pada Tabel 2 warna pupuk cair rata-rata yaitu coklat menuju coklat kehitaman.

Tabel 2. Hasil Pengamatan Uji Organoleptik Warna

\begin{tabular}{|c|c|c|c|}
\hline \multirow[t]{2}{*}{ Perlakuan } & \multicolumn{3}{|c|}{ Hasil Organoleptik Warna } \\
\hline & 1 & 2 & 3 \\
\hline A & $\mathrm{C}$ & $\mathrm{C}$ & $\mathrm{C}$ \\
\hline B & $\mathrm{C}$ & $\mathrm{SC}$ & $\mathrm{C}$ \\
\hline $\mathrm{C}$ & CK & $\mathrm{CK}$ & $\mathrm{SC}$ \\
\hline $\mathrm{D}$ & $\mathrm{CK}$ & $\mathrm{CK}$ & $\mathrm{CK}$ \\
\hline
\end{tabular}

Keterangan:

C : Coklat

SC : Sangat coklat

CK : Coklat Kehitaman

Hal ini berarti penambahan dosis buah nanas berpengaruh terhadap kecepatan kematangan warna pupuk cair. Menurut Sofyan et al. (2007) bau yang ada dalam pupuk cair bersumber dari bahan anorganik yang belum terdegradasi menjadi bahan-bahan organik.

\section{Spesifikasi pupuk organik cair rumput laut}

Hasil analisis unsur hara pupuk organik cair rumput lautE.cottonii, yaitu unsur $\mathrm{N}$ tidak memenuhi standar kualitas pupuk organik karena rendahnya sumber $\mathrm{N}$ yang terdapat di dalam E.cottonii dan buah nanas (A.comosus) yang digunakan dalam proses pengolahannya. Unsur lain yaitu $\mathrm{C}, \mathrm{P}$, dan $\mathrm{K}$ pada pupuk organik cair rumput laut E.cottonii memenuhi standar kualitas pupuk organik.

Perbedaan kandungan unsur hara pupuk cair rumput laut hasil fermentasi dengan pupuk cair rumput laut komersial tersaji pada Tabel 3.
Tabel 3.Perbandingan Unsur Hara Pupuk E.cottonii Fermentasi PGPR dan Pupuk Cair Rumput Laut Komersial

\begin{tabular}{llrl}
\hline $\begin{array}{l}\text { Unsur } \\
\text { Hara }\end{array}$ & $\begin{array}{l}\text { Fermentasi } \\
\text { PGPR }\end{array}$ & Komersial & $\begin{array}{l}\text { Standar } \\
(\mathbf{2 0 1 4})\end{array}$ \\
\hline C $(\%)$ & 7,02 & 36,25 & Min 6 \\
N $(\%)$ & 1,78 & 11,50 & $3-6$ \\
P $(\%)$ & 3,44 & 0,48 & $3-6$ \\
K (\%) & 3,41 & 13,29 & $3-6$ \\
\hline
\end{tabular}

\section{KESIMPULAN}

Kesimpulan yang dapat diambil dari penelitian adalah: Pupuk organik yang dihasilkan dengan penambahan PGPRdanbuah nanasmemiliki kandungan c-organik, fosfor, kalium, pH, bakteri Salmonella sp dan Escherichia coli yang telah memenuhi standar Permentan No. 70/Permentan/SR.140/10/2011.

\section{UCAPAN TERIMA KASIH}

Penulis mengucapkan terima kasih kepada Laboratorium Teknologi hasil Perikanan FPIK-Universitas Diponegoro yang telah membantu kelancaran dalam penelitian ini.

\section{DAFTAR PUSTAKA}

Balai Penelitian Tanah. 2005. Petunjuk Teknis Analisis Kimia Tanah, Tanaman, Air, dan Pupuk. Balai Penelitian Tanah. Bogor. $136 \mathrm{hlm}$.

Basmal. J. 2010. Teknologi Pembuatan Pupuk Cair Kombinasi Hidrolisat Rumput Laut Sargassum sp. dan Limbah Perikanan. Jurnal Squalen Buletin Pascapanen dan BioteknologiKelautan dan Perikanan.,5(2): 59-66.

Biswas J.C, J.K. Ladha, dan F.B. Dazzo. 2000. Rhizobial inoculation improves nutrient uptake and growth of lowland rice. Soil Sci. Soc.Am. J., 64(1): 1644-1650.

Citawaty, Annica. 2011. Pengomposan Limbah Isi Rumen Sapi dengan Penambahan Sekam pada variasi Yang Berbeda. [Skrispi]. Teknik Lingkungan Universitas Diponegoro. Hlm 1-109.

Hapsari, N dan Welasih. 2010. Pemanfaatan Limbah Ikan Menjadi Pupuk Organik. Jurnal Kimia., 2(1): 1-7.

Hidayati, Y.A., T.A. Kurnani., E.T. Marlina dan E. Harlia. 2011. Kualitas Pupuk Cair Hasil Pengomposan Feses Sapi Potong Menggunakan Saccharomyces cereviceae. Jurnal ilmu ternak., 11(2):104-107

Horwitz, W. 2000. Official Methods of Analysis of AOAC International $\quad 17^{\text {th }} \mathrm{ed}, \quad$ AOACInternational, Gaithersburg. Article. pp. 12-35.

Illera-Vivesa, M., S. S. Labandeirab., L.M. Britoc., A. LópezFabala, dan M.E. López- Mosquera. 2015. Evaluation Of Compost From Seaweed And Fish 
Waste As A Fertilizer Forhorticultural Use Scientia Horticulturae. 186(2) 101-107.

Indriani, F. 2013. Studi Pengaruh Penambahan Limbah Ikan pada Pupuk Cair Dari Urin Sapi Terhadap Kandungan Unsur Hara Makro (CNPK). [Skrispi]. Teknik Lingkungan Universitas Diponegoro. Hlm 1-121.

Irma, Y. S, Dan K. Sari. 2015. Perbandingan Jenis Media Tanam Tanah Entisol Yang Terpapar Satu Kali dan Dua Kali oleh Limbah Cair Nanas Terhadap Pertumbuhan Seledri (Apium Graveolens L.) Sebagai Sumber Belajar Biologi. Jurnal Pendidikan Biologi., 6(1): 63-70.

Masuda, T., T. Taniguchi., K. Suzuki., T. Sakai., dan T .Morichi. 2000. Effect of The Difference in The High Molecular Weight Fraction of Whey Between Cow's Milk and Goat's Milk on Creaming Phenomenon. Journal College of Bioresource Science. 1(2): 351-357.

Menteri Pertanian Republik Indonesia. 2011. Peraturan Menteri Pertanian Republik Indonesia Nomor 70 Tahun 2011, tentang Pupuk Organik, Pupuk Hayati, dan Pembenah Tanah.

Menteri Pertanian Republik Indonesia. 2004. Peraturan Menteri Pertanian Republik Indonesia Nomor 02 Tahun 2004, tentang Persyaratan Teknis Minimal Pupuk Organik.
Menteri Pertanian Republik Indonesia. 2009.Peraturan Menteri Pertanian Republik Indonesia Nomor 28 Tahun 2009, tentang Persyaratan Teknis Minimal Pupuk Organik.

Saraswati R, dan Sumarsono. 2008. Pemanfaatan Mikroba Penyubur Tanah Sebagai Komponen Teknologi Pertanian. Iptek Tanaman Pangan., 3(1): 11-67.

Sedayu, B.B., S.E. Made, dan A. Luthfi. 2013. Pupuk Cair dari Rumput Laut Eucheuma Cottonii, Sargassum Sp. dan Gracilaria Sp. menggunakan Proses Pengomposan. JPB Perikanan., 9(1): 61-68.

Setyawan, W. A.,2010. Pemanfaatan Limbah Ikan Menjadi Pupuk Organik. [Skripsi]. Universitas Pembangunan Nasional "Veteran". Hlm 1-35

Sudarmadji, S. 2007. Analisis Bahan Makana dan Pertanian. Liberty Yogyakarta. Yogyakarta. $109 \mathrm{hlm}$.

Sofyan, Ritung., Wahyunto., F. Agus dan H. Hidayat. 2007. Evaluasi Kesesuaian Lahan dengan Contoh Peta Arahan Penggunaan Lahan Kabupaten Aceh Barat.Balai Penelitian Tanah dan World Agroforestry Center.

Stofella, P.J and B. A. Kahn. 2001. Compost Utilization in Holticultural Cropping Systems. Lewish Publisher, USA.

Sutanto, R. 2002. Penerapan Pertanian Organik. Kanisius. Yogyakarta. $90 \mathrm{hlm}$. 